UDC 338:486.1

DOI: https://doi.org/10.32847/business-navigator.60-23

Tsviliy Sergiy

Candidate of Economic Sciences, Associate Professor,

Senior Lecturer at the Department of Tourism, Hotel and Restaurant Business National University "Zaporizhzhia Polytechnic"

Gurova Darya Candidate of Geographical Sciences, Associate Professor, Senior Lecturer at the Department of Tourism, Hotel and Restaurant Business National University "Zaporizhzhia Polytechnic"

Korniienko Olga

Candidate of Economic Sciences, Associate Professor,

Senior Lecturer at the Department of Tourism,

Hotel and Restaurant Business

National University "Zaporizhzhia Polytechnic"

Цвілий С.М.

кандидат економічних наук, доцент, доцент кафедри туристичного, готельного та ресторанного бізнесу Національний університет "Запорізька політехніка"

Гурова Д.Д. кандидат географічних наук, доцент, доцент кафедри туристичного, готельного та ресторанного бізнесу Наиіональний університет "Запорізька політехніка"

Корнієнко О.М. кандидат економічних наук, доцент, доцент кафедри туристичного, готельного та ресторанного бізнесу Національний університет "Запорізька політехніка"

\title{
POST-CORONAVIRUS DEVELOPMENT OF THE REGIONAL TOURIST DESTINATION ON THE PRINCIPLE OF PUBLIC-PRIVATE PARTNERSHIP
}

Tsviliy Sergiy, Gurova Darya, Korniienko Olga. Post-coronavirus development of the regional tourist destination on the principle of public-private partnership. The article discusses the ways of finding effective approaches to the development of tourist destinations in the post-coronavirus economy of the regions on the basis of public-private partnership. The basic principles of public-private partnership and benefits for the state, business, the population of the destination are highlighted. The stages and fundamental factors for the success of building a public-private partnership management system in a tourist destination are proposed. It has been determined that the key to the success of entrepreneurs will be: firstly, the level of residents of the tourist destination; secondly, the aesthetics of the tourism business; thirdly, innovative guest service models. The tools for active involvement are structured in order to ensure the post-coronavirus development of the tourist destination.

Key words: tourist destination, public-private partnership, hospitality sphere, post-coronavirus economy, regional development.

Цвилый С.Н., Гурова Д.Д., Корниенко О.Н. Посткоронавирусное развитие туристической дестинации региона на принципах государственно-частного партнерства. В статье рассмотрены пути поиска действенных подходов к развитию туристических дестинаций в посткоронавирусний экономике регионов на основе государственно-частного партнерства. Выделены базовые принципы государственно-частного партнерства и выгоды для государства, бизнеса, население дестинации. Предложены этапы и фундаментальные факторы успеха построения системы управления государственно-частным партнерством в туристической дестинации. Определено, что залогом успеха предпринимателей станут: во-первых, уровень жителей туристической дестинации; во-вторых, эстетика туристического бизнеса; в-третьих, инновационные модели обслуживания гостей. Структурировано инструментарий для активного задействования с целью обеспечения посткоронавирусного развития региональной туристической дестинации.

Ключевые слова: туристическая дестинация, государственно-частное партнерство, посткоронавирусная экономика, региональное развитие. 
Цвілий С.М., Гурова Д.Д., Корніснко О.М. Посткоронавірусний розвиток туристичної дестинації регіону на засадах державно-приватного партнерства. В статті розглянуто шляхи пошуку дієвих підходів до розвитку туристичних дестинацій у посткоронавірусній економіці регіонів на засадах державно-приватного партнерства. Доведено, в умовах пошуку альтернатив виходу з глобальної туристичної кризи вивчення державно-приватного партнерства в економіці доцільно здійснювати з позицій геопросторового, структурного і системно-функціонального підходів. Виокремлено базові засади державно-приватного партнерства, а також основні вигоди для держави, як публічного партнера; бізнесу, як приватного партнера, населення туристичної дестинації. Запропоновано етапи і фундаментальні фактори успіху побудови системи управління державно-приватним партнерством в туристичній дестинації. Визначено, що основними запоруками успіху підприємців регіону в посткоронавірусному розвитку туристичної дестинації стануть: по-перше, культурний рівень мешканців туристичної дестинації; по-друге, естетика туристичного бізнесу; по-третє, інноваційні моделі обслуговування гостей. Структуровано інструментарій, який слід активно задіяти для забезпечення посткоронавірусного розвитку регіональної туристичної дестинації. Зроблено висновок, що стратегічне підготування до посткоронавірусних економічних умов на рівні окремої регіональної туристичної дестинації потрібує розробки та впровадження комплексної збалансованої системи заходів соціальноекономічного, правового й адміністративно-управлінського характеру, яка має на меті створення умов для розвитку якісно нового рівня потенціалу в туризмі і забезпечення формування сталих конкурентних переваг конкретної території з одночасним забезпеченням стабільної диверсифікованої зайнятості населення та можливості участі в реалізації проектів підприємницькими структурами середнього, малого та мікробізнесу регіону. Обгрунтовано напрямки перспективних досліджень, які будуть мати науковий сенс у дослідженні активізації зусиль учасників державно-приватного партнерства в туристичній дестинації щодо повноцінної цифровізації стосунків та процесів.

Ключові слова: туристична дестинація, державно-приватне партнерство, сфера гостинності, посткоронавірусна економіка, регіональний розвиток.

Formulation of the problem. In the conditions of unalterable modern challenges of the global environment, unstable external environment, stagnation in business, unfavorable market space conditions and intense competition among enterprises in domestic tourist destinations, the search for forms of development of this sphere is becoming more and more obvious. The logical reaction of tourism enterprises to the dynamics of changes in local economic systems caused by the COVID-19 pandemic is the search for new forms of interaction with regional markets, the main determinant of which is focusing on partnerships as a set of mutually agreed processes and operations aimed at achieving goals of the tourist destination. One of the basic prerequisites for effective post-coronavirus development of a tourist destination is the organization of public-private partnership (PPP) on an innovative basis, which should provide preventive leveling of the negative impact of global economic factors and should be a powerful tool for strengthening the competitive position of tourism enterprises within the region.

Analysis of recent research and publications. Theoretical and methodical, and conceptual approaches to the functioning of certain mechanisms of public-private partnership in tourism are presented in the works of M. Boiko, M. Bosovska, O. Yevtushenko, T. Lutska, A. Mazaraki, S. Melnychenko, I. Melnyk, T. Mizerna, A. Nalyvaiko, T. Pulina, N. Sviridova, T. Tkachenko and others [2]. Specific features of the regulation of PPP development are occasionally covered in the studies of such domestic and foreign scientists as: Yu. Aleksieieva, A. Durovich, V. Kifyak, K. Pavliuk, M. Porter, R. Harrod, V. Tsybukh, etc., presentation of opinions which added a significant contribution to the classical knowledge of this issue [4]. Practical aspects of the implementation of PPP tools in local tourist destinations are considered in the scientific works of $\mathrm{H}$. Brusiltseva, A. Vindiuk, V. Zaitseva, L. Ivashova, Y. Karpenko, H. Skliar, D. Soloviova, D. Stechenko, P. Shelepnytskyi
$[1 ; 3 ; 6-10 ; 12]$ and others. However, in the presence of a significant number of scientific ideas of domestic and foreign scientists today, there are almost no comprehensive studies on the formation of effective approaches to the development of tourist destinations in the post-coronavirus economy of the regions on the basis of public-private partnership.

Formulation of the goals of the article. The purpose of the article is to substantiate the principles of tourist destination development on the basis of public-private partnership taking into account the impact of post-coronavirus factors of the global environment.

Presenting main material. The development of tourism in the region is possible only with the support of the state and this is primarily due to state ownership of active tourist infrastructure, as well as historical and cultural monuments [11]. However, financial resources are needed to develop the infrastructure and maintain the cultural heritage in each tourist destination, especially at the municipal level. That is why regional and municipal authorities are interested in cooperating with business structures to attract additional investment. In a trivial sense, the implementation of joint projects is accompanied by a guarantee by the administrative authorities of stable conditions and certain benefits for entrepreneurs, as well as their participation in decision-making on the development of the tourism sector of the region and the city. Even with the common interests of regional authorities and private companies in the field of tourism, they have different goals: the authorities are interested in demonstrating the provision of various benefits in a certain amount and quality, and the space of business interests is to make a profit [5]. However, the general sphere of their interests includes the conditions and quality of life of the local population, ensuring the ecological and socio-economic development of the region and its hospitality, which contributes to increasing the tourist flow and sustainability of the tourist destination. 
A study of the coronavirus practice of public-private partnership in regional tourist destinations proved that their development was carried out through the creation of a system of indicators of tourism potential of the region. These include geographical, ecological and demographic characteristics of the territory, the level of urbanization; availability and condition of recreational areas (reserves and national parks, objects of historical and cultural heritage, health and tourist bases); level of infrastructure development (availability of equipped trade-exhibition and hotel complexes for holding fairs and congresses and their location, general level of communal infrastructure development); creation of a system of small and medium business, which ensure the comprehensive development of the tourism industry; activity of legislative and executive bodies of all levels in the development of the tourism and recreation industry; the presence of educational institutions that provide training in the field of tourism and ensure the implementation of service and excursion programs. Taking into account this system of indicators, the goal was to develop a set of measures for the implementation of public-private partnership in a specific area.

In search of ways out of the global tourism crisis caused by the COVID-19 pandemic, the study of public-private partnerships in the economy should be carried out from the standpoint of geospatial, structural, systemic functional approaches, which, in turn, is associated with building organizational models of cooperation between administrative and commercial structures in the destination through the involvement of other partner organizations, which will lead

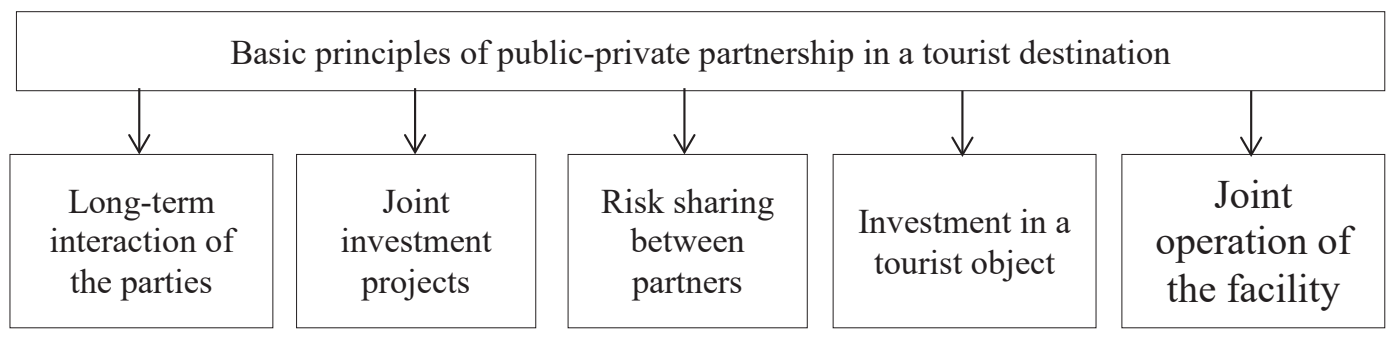

Figure 1. Principles of public-private partnership in a tourist destination

\begin{tabular}{|c|c|}
\hline Stage 1 & $\begin{array}{l}\text { Study of the world's interactive experience in building PPP. } \\
\text { Research of the role of the state in similar structures. } \\
\text { Analysis of the infrastructure of the tourist services market. }\end{array}$ \\
\hline \multirow[b]{2}{*}{$\downarrow$} & Development of basic concepts and procedures of partnership. \\
\hline & $\begin{array}{l}\text { Formation of bases of policy of tourist destination. } \\
\text { Introduction of the regulatory framework of PPP. }\end{array}$ \\
\hline Stage 2 & Publication of practical instructions for partners. \\
\hline \multirow[b]{2}{*}{$\downarrow$} & Launch of PPP operation for all participants in the real sphere. \\
\hline & $\begin{array}{l}\text { Creating a virtual space for PPP participants. } \\
\text { Formation of basic, additional and service structures. }\end{array}$ \\
\hline Stage 3 & Attracting alternative sources of financing and investment. \\
\hline \multirow[b]{2}{*}{$\downarrow$} & $\begin{array}{l}\text { Development of conditions for the provision of extra-project services } \\
\text { by participants. }\end{array}$ \\
\hline & Concluding a long-term political consensus. \\
\hline Stage 4 & $\begin{array}{l}\text { Opening access to projects to foreign investors. } \\
\text { Stabilization of relations between partners within the PPP. }\end{array}$ \\
\hline \multirow[b]{2}{*}{$\downarrow$} & $\begin{array}{l}\text { Providing digital education to participants of the leading higher education } \\
\text { institutions of the region. } \\
\text { Elimination of final legal barriers to the functioning of the PPP. }\end{array}$ \\
\hline & Introduction of the \\
\hline Stage 5 & $\begin{array}{l}\text { Formation of business philosophy and ethical values. } \\
\text { Assessment of participants' compliance with the goals of the tourist destination. } \\
\text { PPP development forecasting and model building. } \\
\text { Archiving of accumulated experience within the destination. }\end{array}$ \\
\hline
\end{tabular}

Figure 2. Stages of building a management system for public-private partnership in a tourist destination Source: proposed by the authors 
to a mandatory redistribution of functions and responsibilities of the parties. The coordination structure of this format should unite regional executive bodies, tourism industry enterprises, entrepreneurs, educational institutions, business associations, public organizations and the local population. Coherence of actions of the main participants of the regional tourist destination, according to the authors, will allow to implement innovative ideas, startup projects and public programs within the framework of PPP on the local territory effectively. It should be added that the main priority in building the architecture of a tourist destination should be the interaction of partner groups, their interests and motivation. Undoubtedly, PPP should bring certain benefits to the tourist destination, namely: intensive development of tourism infrastructure (1); increasing the quality of the tourist product (2); improving the consumer quality of construction and operation facilities (3); diversified access to private capital markets (4); preferential taxation (5); growth of labor value (6); release and redistribution of different types of resources (7). Such a partnership should be based on certain principles, which are presented in Figure 1.

It is stated that the implementation of such principles requires new effective forms of PPP management, which cannot be created without appropriate in-depth study. The authors proposed five stages to build a PPP management system in a tourist destination based on the study of experience (Figure 2).

In order to build an effective PPP management system in a tourist destination quickly, the authors identified the following fundamental success factors: stable political situation in the region and the absence of visible political risks that could negatively affect the implementation of public-private partnership projects (1); the political will of public authorities and senior officials to use the latest mechanisms of public-private partnership for the development of the regional tourist destination (2); high level of investment attractiveness of the region and stable forecast indicators of its socio-economic development in the post-coronavirus economy (3); the state bodies of the region have an understanding of the need to form an effective system of state strategic planning: a set of goals, sequence of actions, priorities for the development of tourism potential of the region in the short, medium and long term using forecasting, targeting and programming mechanisms (4); the real focus and desire of the state bodies of the region to more actively involve private companies in the provision of services in the sectors of industries that are integrated into the tourism sector of the region (5); availability of competent specialists with professional knowledge, skills and abilities in the field of PPP, public administration and infrastructure development of a regional tourist destination (6); a systematic approach to the development of the hospitality sector of the regional tourist destination infrastructure and investment attraction (7).

From this point of view, the importance of using the PPP mechanism in the development of a tourist destination is weighed and substantiated, which is explained by the excessive burden of this area for the state and regional communities. Thus, traditionally private businesses, entrepreneurs and other stakeholders receive about $90 \%$ of profits from operating tourism activities, while government spending to support the tourism infrastructure of a particular region is significant and not covered by income. Private large and medium-sized enterprises in such a partnership have the opportunity to invest and receive a guaranteed profit in the long run, and tourism enterprises of small and micro businesses have the opportunity to submit innovative ideas and startup projects for testing. The positive impact of PPP is also expected in solving the socio-economic problems of the tourist destination and is, above all, that it diversifies the employment of the population and it provides residents of a particular area additional income in the field of tourist services, which in turn stimulates the development of services: transport, communications, trade, household services, recreation and entertainment, others. This approach will provide new opportunities for entrepreneurs in the post-coronavirus economy of the region.

It should also be emphasized that the main keys to the success of entrepreneurs in the region in the post-coronavirus development of a tourist destination will be: first, the cultural level of the inhabitants of the tourist destination; secondly, the aesthetics of the tourism business; third, innovative customer service models. In general, in order to better understand the tasks of PPP goals in a tourist destination, it is necessary to define the goals of participation of each of the partners in development projects and innovation plans and opportunities to benefit from their successful implementation. The goals of the state, as a public partner, are: to improve the quality, accessibility and expansion of the range of services to the population (1); growth of indicators of economic efficiency of projects due to reduction of expenses and risks, increase of level of quality of services (2); reducing the level of bureaucratization and corruption in the region's tourism economy by attracting a private partner on flexible decision-making conditions (3); gaining access to alternative sources of capital for the implementation of important and urgent projects in tourism (4); reducing the burden on the budget by increasing the efficiency of budget expenditures (5); reliability of results due to timely implementation of the project, as well as the order of return on investment and compensation of current costs (6); access to innovations in the field of tourism due to modern organizational experience, knowledge and new digital technologies of a private partner (7); implementation of strategically important infrastructure projects of a tourist destination (8); implementation of innovative solutions for the development of state property (9); use of experience, skills and competencies of private business with partial preservation of state control over assets (10); promoting the introduction of innovative management principles in public authorities (11); increasing the efficiency and competitiveness of service and ancillary sectors of the economy of the regional tourist destination (12). The goals of the business, as a private partner, are: reduction of the tax burden in the form of receiving tax benefits and preferences (1); acquisition of state assets in possession and use over a long period of time in order to ensure stable profits in the long run (2); state guarantees of return on investment (3); increasing the degree of maneuverability and freedom of administrative and economic decision-making and removing a number of bureaucratic delays to increase the efficiency of innovative decision-making (4). The goals of the population of a regional tourist destination are: creation of a favorable environment for the emergence of alternative forms of innovation (1); access to quality digital services (2); intensification of business processes in the regional tourist environment (3); stimulating entrepreneurial thinking in search of promising methods of interaction 
in the field of hospitality (4); promoting the latest dialogue between government and business (5).

In general, to ensure the post-coronavirus development of a regional tourist destination, it is advisable to accelerate the implementation of the following tools of public-private partnership: rapid removal of legislative and procedural restrictions (1); quality preparation of investment projects (2); ensuring transparent conditions of concession agreements (3); creation of coordination virtual structures (4); improving the transport and engineering infrastructure of the tourist destination (5); identification of priority project areas (6); program-targeted partnership investments (7); providing benefits for taxes, loans, subsidies, guarantees, sureties (8); creation of regional virtual tourist hubs (9); partnership financing of the marketing component of destination development projects (10). Strategic preparation for post-coronavirus economic conditions at the level of a separate domestic regional tourist destination requires the development and implementation of a comprehensive balanced system of socio-economic, legal and administrative measures aimed at creating conditions for the development of a qualitatively new level of tourism potential formation of sus- tainable competitive advantages of a particular territory while ensuring stable diversified employment and opportunities for participation in projects by business structures of small and micro businesses in the region.

Conclusions. Public-private partnership in Ukraine as a condition for guaranteeing the safe sustainable development of a tourist destination in the post-coronavirus world is possible only if the interests and needs of all its participants are combined. In particular, investors need to be confident in return on investment, as tourism innovation ideas have a significant degree of risk, which is caused by the high capital intensity of infrastructure projects for the tourism business and too long payback periods with unknown end results. Therefore, along with the development of infrastructure, administrative authorities must share the risks of private investors and provide long-term guarantees for the fulfillment of their obligations: favorable lease of land, tax benefits, long-term loans at low interest rates, opportunities to hire foreign staff and others. Further scientific interest should be supported by research on intensifying the efforts of participants in public-private partnerships in tourist destinations in the direction of full digitalization of relations and processes through the use of leading experience of domestic specialists and companies.

\section{References:}

1. Brusiltseva, H.M. (2015) Analiz tendentsiy rozvytku derzhavno-pryvatnoho partnerstva v turystychniy haluzi Ukrayiny [Analysis of trends in the development of public-private partnership in the tourism industry of Ukraine]. Yevropeys'ki perspektyvy-European perspectives, 6, 26-31. (in Ukrainian)

2. Hurova, D.D. (2019) Suchasnyy ekonomichnyy vplyv turyzmu [The modern economic impact of tourism]. Priazovsky ekonomichnyi visnyk - Priazovsky economic bulletin, 6(17), 3-7.

3. Ivashova, L.M. (2018) Derzhavno-pryvatne partnerstvo u sferi turyzmu yak diyevyy mekhanizm zabezpechennya staloho rozvytku ekonomiky krayiny ta rehioniv [Public-private partnership in the field of tourism as an effective mechanism for ensuring sustainable economic development of the country and regions. Public administration \& customs regulation]. Publichne upravlinnya ta mytne rehulyuvannya - Public administration and customs regulation, 1(18), 52-61. (in Ukrainian)

4. Mamotenko, D.Yu. (2019) Derzhavno-pryvatne partnerstvo u sferi turyzmu [Public-private partnership in the field of tourism]. Proceedings from: Mizhnarodna naukovo-praktychna konferenciia "Turyzm XXI: hlobal'ni vyklyky ta tsyvilizatsiyni tsinnosti"- International Scientific and Practical Conference "Tourism of the XXI: global challenges and civilization values". Kyiv: KNTEU, pp. 128. (in Ukrainian)

5. Rybintsev, V.O., Tsviliy, S.M., Mykhailyk, D.P. (2010) Orhanizatsiya derzhavno-pryvatnoho partnerstva v Zaporiz'kiy oblasti [Organization of public-private partnership in Zaporizhia region]. Ekonomichnyy visnyk Natsional'noho hirnychoho universytetu - Economic Bulletin of the National Mining University. Ser: Ekonomika rehioniv - Economy of the regions, 2(30), 6-11.

6. Shylepnytskyi, P.I. (2011) Derzhavno-pryvatne partnerstvo: teoriya i praktyka [Public-private partnership: theory and practice]. Chernivtsi: Instytut rehionalnykh doslidzhen'. (in Ukrainian)

7. Skliar, H.P., Karpenko, Yu.V. (2015) Derzhavno-pryvatne partnerstvo v sferi hastronomichnoho turyzmu yak instrument modernizatsiynoho rozvytku ekonomiky rehioniv [Public-private partnership in the field of gastronomic tourism as a tool for modernization of regional economies]. Ekonomichnyy visnyk Donbasu - Economic Bulletin of Donbass, 1(39), 98-104. (in Ukrainian)

8. Soloviov, D.I. (2013) Vprovadzhennya elementiv derzhavno-pryvatnoho partnerstva u funktsionuvannya turystychnoyi sfery Ukrayiny [Introduction of elements of public-private partnership in the functioning of the tourism sector of Ukraine]. Visnyk Berdyans'koho universytetu menedzhmentu i biznesu - Bulletin of Berdyansk University of Management and Business, № 4(24), 33-36. (in Ukrainian)

9. Stechenko, D.M., Bezuhlyi, I.V. (2014) Imperatyv derzhavno-pryvatnoho partnerstva v rekreatsiyno-turystychniy sferi Ukrayiny [Imperative of public-private partnership in the recreational and tourist sphere of Ukraine]. Rehional'na ekonomika Regional economy, 2, 136-146. (in Ukrainian)

10. Vindiuk, A.V. (2019) Turystychna osvita: zakordonnyy ta vitchyznyanyy dosvid. Perspektyvy rozvytku turyzmu v Ukrayini [Tourism education: foreign and domestic experience. Prospects for tourism development in Ukraine]. Ternopil': Pidruchnyky i posibnyky. (in Ukrainian)

11. Zakon Ukrayiny "Pro derzhavno-pryvatne partnerstvo" [The Law of Ukraine "On public-private partnership"]. Retrieved from: https://zakon.rada.gov.ua/laws/show/2404-17\#Text (in Ukrainian)

12.Zaitseva, V., But, T., Hres-Yevreinova, S. (2018) Assessment of the competitiveness of tourist cluster of Zaporizhzhia region [Otsinka konkurentospromozhnosti turystychnoho klasteru Zaporiz'koyi oblasti]. Strategies for Economic Development: The experience of Poland and the prospects of Ukraine - Stratehiyi ekonomichnoho rozvytku: Dosvid Pol'shchi ta perspektyvy Ukrayiny, vol. 2, pp. 61-74. Poland: Izdevnieciba "Baltija Publishing". 